\section{a $\begin{gathered}\text { SWV } \\ \text { (norm to peak) }\end{gathered}$}
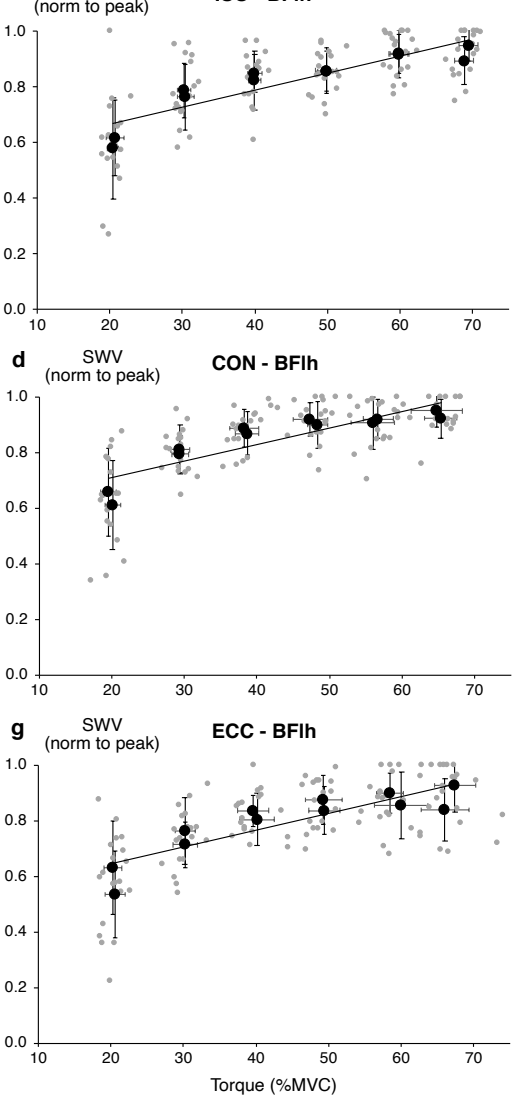

(norm to peak) ISO - ST
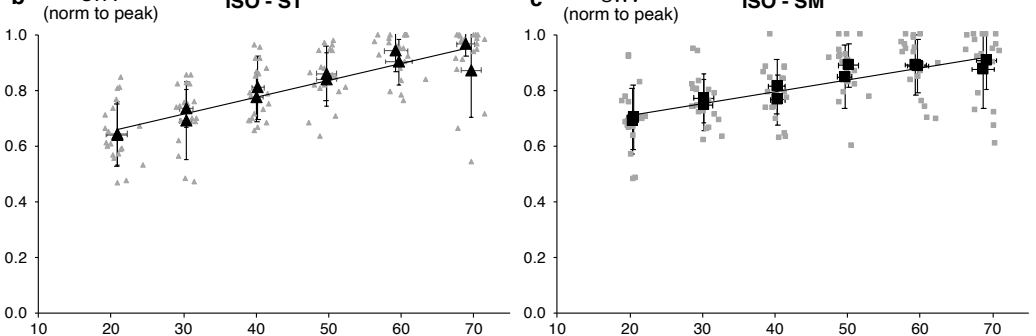
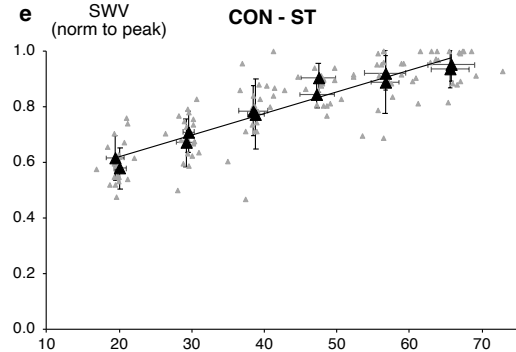
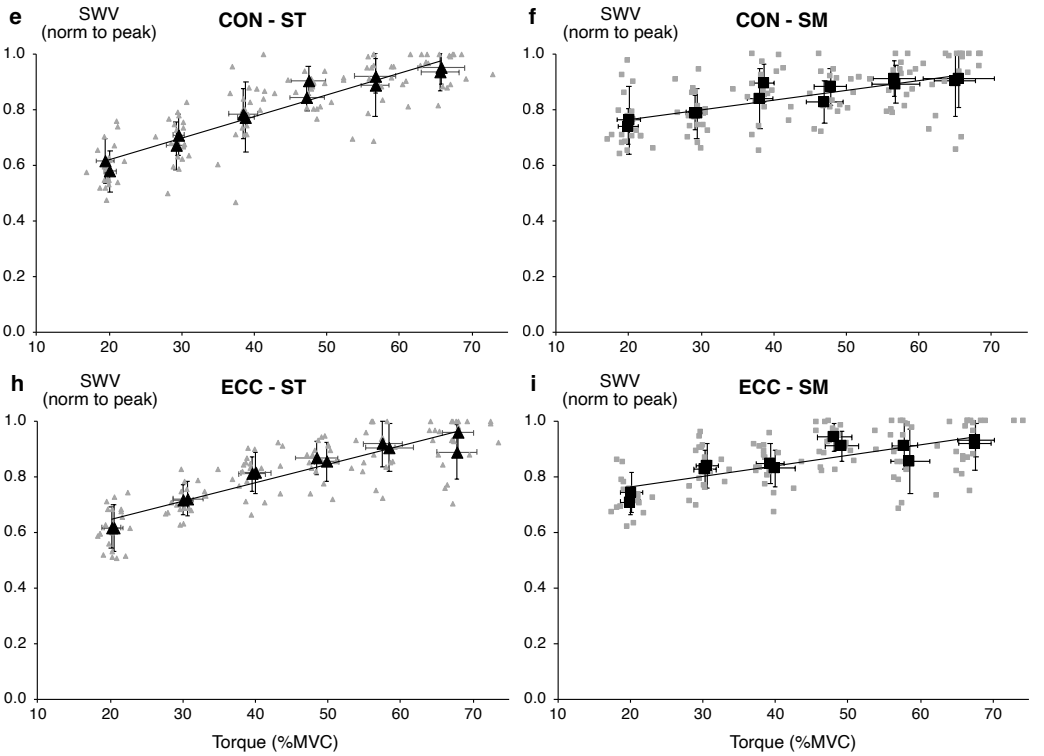